\title{
Prediction Validity of Teaching Efficacy on Task-Centered Anxiety: A Study on Physical Education Teacher Candidates*
}

\section{Öğretim Yeterliğinin Görev Merkezli Kaygı Üzerindeki Yordama Geçerliği: Beden Eğitimi Öğretmen Adayları Üzerine Bir Çalışma}

\author{
Mustafa Kayıhan ERBAŞ ${ }^{* *}$ (iD) Hüseyin ÜNLÜ ${ }^{* * *}$ (iD
}

Received: 02 August 2020

Research Article

Accepted: 01 October 2020

ABSTRACT: This study aimed to determine the relationship between physical education teacher candidates' teaching efficacy and task-centered anxieties. Correlation survey model was used in this research. The research group consisted of 228 prospective physical education teachers, 84 of whom were female (37\%) and 144 were male (63\%), who were educated in the 3rd and 4th grades in 5 different universities. Personal information form, Teacher Occupational Anxiety Scale and Physical Education Teaching Efficacy Scale were used as data collection tools. In the analysis of the data in the research descriptive statistics were used. In advanced analysis, Pearson Moments Product Correlation Coefficient technique was used to determine the level and direction of the relationship between the teaching efficacy and task-centered anxiety levels of the physical education teacher candidates. In addition, whether the teaching efficacy levels of the physical education teacher candidates are predicting the task-centered anxiety levels were tested by multi-directional regression analysis. As a result of the analysis, It was determined that there was a moderate positive correlation between total teaching efficacy levels and task-centered anxiety levels, and when the results regarding the significance of regression coefficients were analyzed, only total teaching efficacy levels were significant and significant predictors of task-centered anxiety levels.

Keywords: Physical education teacher, teaching efficacy, task-centered anxiety.

ÖZ: Bu çalışmanın amacı; beden eğitimi öğretmeni adaylarının öğretim yeterlikleri ile görev merkezli kaygıları arasındaki ilişkinin incelenmesidir. Bu araştırmada ilişkisel tarama modeli kullanılmıştır. Araştırma grubunu, 5 farklı üniversitede 3. ve 4. sınıfta eğitim gören eğitim gören 84'ü kadın (\%37) ve 144’ü erkek (\%63) olmak üzere 228 beden eğitimi öğretmeni adayı oluşturmuştur. Veri toplama aracı olarak kişisel bilgi formu, mesleki kaygı ölçeği ve beden eğitimi öğretim yeterlik ölçeği kullanılmıştır. Araştırmada verilerin analizinde tanımlayıcı istatistiklerden faydalanılmıştır. İleri analizlerde ise beden eğitimi öğretmeni adaylarının öğretim yeterlikleri ile görev merkezli kaygı düzeyleri arasındaki ilişkinin düzeyi ve yönünü belirlemek amacıyla Pearson Momentler Çarpımı Korelasyon Katsayısı tekniği kullanılmıştır. Bunun yanında beden eğitimi öğretmeni adaylarının öğretim yeterlik düzeylerinin görev merkezli kaygı düzeylerini yordayıp yordamadığı, çok yönlü regresyon analizi ile test edilmiştir. Analizler sonucunda, toplam öğretim yeterliği düzeyleri ile görev merkezli kaygı düzeyleri arasında pozitif yönde orta düzeyde bir ilişki olduğu ve regresyon katsayılarının anlamlılı̆̆ına ilişkin sonuçlar incelendiğinde ise sadece toplam öğretim yeterlik düzeylerinin görev merkezli kaygı düzeyleri üzerinde anlamlı ve önemli bir yordayıcı olduğu belirlenmiştir.

Anahtar kelimeler: Beden eğitimi öğretmeni, öğretim yeterlik, görev merkezli kaygı.

\footnotetext{
* A part of abstract of this study was presented as a verbal paper at the 15th International Congress of Sports Sciences.

** Corresponding Author: Assoc. Prof. Dr., Aksaray University, Aksaray, Turkey, kayihan.besyo@gmail.com, https://orcid.org/0000-0003-0515-9099

*** Prof. Dr., Aksaray University, Aksaray, Turkey, unlu68@ gmail.com, https://orcid.org/0000-0002-3079-4417
}

Citation Information

Erbaş, M. K., \& Ünlü, H. (2020). Prediction validity of teaching efficacy on task-centered anxiety: A study on physical education teacher candidates. Kuramsal Eğitimbilim Dergisi [Journal of Theoretical Educational Science], 13(4), 701-715.

Copyright (C) 2020 by AKU

ISSN: $1308-1659$ 
It is a known fact that the concept of efficacy, which is an indispensable element for every professional group, is also of great importance for the teaching profession. The concept of self-efficacy, which is stated to have an important place in Social Cognitive Theory (Güngör \& Yayl1, 2012; Senler, 2016); it has been observed that people are defined as their judgment about their ability to organize and execute action plans needed to achieve expected performances (Bandura, 1986). Accordingly, teacher efficacy; despite all the negativities, it was seen that the teacher was expressed as their beliefs and opinions that they could enable students to learn better (Deringöl, 2018; Guskey \& Passaro, 1994). In addition, it has been stated that one of the strongest predictors of teachers' pedagogical decisions and effectiveness is the professional efficacy of the teacher (Summers, Davis, \& Woolfolk Hoy, 2017).

The education of teachers, an indispensable element of education in developed and developing countries, and "How to train qualified teachers?" it was stated that an answer to the question was sought (Bedir, 2015; Price \& Weatherby, 2018). Located in Turkey in the category of developing countries; it was observed that the general efficacy of the teaching profession for all teaching branches were determined by making an update on the teacher efficacy by the Ministry of National Education (MoNE, 2017). According to this, it has been determined that the general efficiencies areas of the teaching profession are grouped under three main headings as (1) knowledge, (2) skills and (3) attitudes and values (Table 1).

Table 1

Efficiencies for Teaching Profession (MoNE, 2017).
(1) Knowledge
(2) Skills
(3) Attitudes \& Values

1.1. Field knowledge

2.1. Education planning

3.1. National, spiritual \& universal values

1.2. Field education knowledge

2.2. Creating learning environments

3.2. Approach to students

2.3. Managing the teaching \& learning

3.3. Communication \&

1.3. Legislation process

collaboration

knowledge

2.4. Quantification and consideration

3.4. Personal \& professional

development

When the researches are examined it was stated that the professional efficacy level of the teacher directly affects the performance of the teacher (Boz, 2008) and in this direction, it was seen that the most important factor in the increase of the proficiency level was pre-service education and its quality (Woolfolk Hoy \& Davis, 2005). In other words prospective teachers' feelings of preparation are determined to be an important determinant of their teaching self-efficacy as well as their ability to fulfill their teaching duties (Housego, 1990). It is stated that the most important factors that increase the pre-service quality are the teaching experience, applied education as well as the observation of experienced teachers (Brown, Lee, \& Collins, 2015).

Similar results have been found in studies investigating the teaching efficacy of physical education teachers and prospective teachers (Humphries, Hebert, Daigle, \& 
Martin, 2012; Martin \& Kulinna, 2005). A qualified teaching environment that will be offered to physical education teacher candidates, can give them proficiency in fulfilling the requirements of the profession. It has been observed that it also affects the viewpoints and feelings and thoughts about the profession (Aydın \& Tekneci, 2013; Taşğın, 2006; Ünlü \& Erbaş, 2018).

It is stated that one of the most prominent concepts among emotions about teaching profession is the concept of professional anxiety (Cabı \& Yalçınalp, 2013). It has been observed that one of the most important determinants of professional anxiety in terms of teachers is the quality of pre-service education, as well as the experience gained in pre-service education and the opportunity for applied education (Kırbaşlar, Veyisoğlu, \& Özsoy-Güneş, 2015).

By many researchers (Cabı \& Yalçınalp, 2013; Saban, Korkmaz, \& Akbaşl1, 2004) anxieties about the prospective teachers are given at specific times that concentrate on specific points. These anxieties are grouped under three main headings (Cochran-Smith, 2000; Fuller, 1969); (a) self-centered anxieties, (b) task-centered anxieties, and (c) student-centered anxieties. It is determined that the focus of the selfcentered anxieties is the individual, and the focus of the task-centered anxieties is the teaching task of the individual and the focus of the student-centered anxiety is the students (Taşğın, 2006).

It has been stated that a teacher candidate who has task-centered anxiety is concerned about being a good teacher and therefore will start to research new teaching methods, materials and equipment that she/he can use in her/his field (Cab1 \& Yalçınalp, 2013). In this direction; the task-centered anxiety (Meek \& Behets, 1999), which acknowledged as a focal point of a teacher candidate's teaching task, was thought to be directly related to the teaching efficacy of teacher candidates.

When the literature is examined some studies in the field of vocational anxiety towards physical education teacher candidates (Bartholomew, Ntoumanis, Cuevas, \& Lonsdale, 2014; Kafkas, Açak, Çoban, \& Karademir, 2010; Taşğın, 2006) were found. In addition, there are studies examining the relationship between physical education teaching efficacy and professional anxiety (Meek \& Behets, 1999). However, no research was found on the relationship between the teaching efficacy of the teacher candidates and task-centered anxiety. It was considered as an important situation to determine the teaching efficacy, professional anxiety levels of the physical education teacher candidates and to reveal the direction and level of the relationship between these two variables. In this direction, it is aimed to investigate the relationship between the teacher efficacy of the physical education teacher candidates and their task-centered anxiety in this study. In line with this general purpose, the sub-problems of the research are listed below:

1. What is the level of teaching efficacy and task-centered anxiety of physical education teacher candidates?

2. Do the teaching efficacy levels and task-centered anxiety levels of the physical education teacher candidates differ according to gender, grade and sports branch variables?

3. Is there any relationship between teaching efficacy and task-centered anxiety of physical education teacher candidates? 
4. Do the teaching efficacy levels of physical education teacher candidates predict their task-centered anxiety levels?

\section{Method}

This research is designed in correlational survey model. Correlation survey model; It is used in studies aiming to determine the existence of a change in two or more variables and the degree of this change (Karasar, 2009).

\section{Research Group}

The research group consisted of 228 prospective physical education teachers studying at 3rd and 4th grades in 5 different universities. Descriptive statistics of the research group are given in Table 2. 3rd and 4th grades prospective physical education teachers were selected due to the content of the data collection tools used.

Table 2

Descriptive Statistics of the Research Group

\begin{tabular}{|c|c|c|c|}
\hline & Variables & $f$ & $\%$ \\
\hline \multirow{2}{*}{ Gender } & Female & 84 & 37 \\
\hline & Male & 144 & 63 \\
\hline \multirow{2}{*}{ Grade } & 3rd grade & 130 & 57 \\
\hline & 4th grade & 98 & 43 \\
\hline \multirow{2}{*}{ Sports Branch } & Individual sports & 88 & 36 \\
\hline & Team sports & 140 & 64 \\
\hline
\end{tabular}

\section{Data Collection Tools}

Procedure. This study was carried out by obtaining an approval report from the Aksaray University Human Research Ethics Committee $\left(6^{\text {th }}\right.$ meeting dated on 22.06.2020, Decision number: 2020/06-91). Accordingly, all data was collected in accordance with the ethical rules. Physical education teacher candidates who participated in the study were informed by researchers about scales, study and data analyses. All teacher candidates voluntarily participated in the study.

Personal information form. This form included the items regarding the genders, grades and sports branch of the physical education teacher candidates who participated in this study.

Physical Education Teaching Efficacy Scale (PETES). PETES, originally was developed by Humphries et al. (2012) and was adapted in Turkish by Erbaş, Varol, and Ünlü (2014); consisted of factors such as (a) efficacy about PE content knowledge $\left(1^{\text {st }}\right.$ sub-dimension), (b) efficacy for applying scientific knowledge in teaching PE ( $2^{\text {nd }}$ subdimension), (c) efficacy about accommodating skill level differences ( $3^{\text {rd }}$ subdimension), (d) efficacy for teaching students with special needs $\left(4^{\text {th }}\right.$ sub-dimension), 
(e) efficacy about instruction ( $5^{\text {th }}$ sub-dimension), (f) efficacy for using assessment $\left(6^{\text {th }}\right.$ sub-dimension) and ( $\mathrm{g}$ ) efficacy for using technology ( $7^{\text {th }}$ sub-dimension) and 35 items.

Each expression that takes place in the scale has a rating Likert type (1) "I can't do", (2) "I can do in medium level", and (3) "I can do in high level". Scoring the scale determined as; 35-49 points are very low level, 50-64 points low level, 65-79 points medium level, 80-94 points high level and 95 and above are very high level. Researchers (Humphries et al., 2012) have used internal consistency Cronbach Alpha parameters to calculate the reliability of the scale. Cronbach Alpha parameter that expressed the internal consistency of the items was calculated it was determined as .94 for the general of the scale. The $1^{\text {st }}$ sub-dimension was calculated as .73 , the $2^{\text {nd }}$ subdimension was calculated as .70 , the $3^{\text {rd }}$ sub-dimension was calculated as .76 , the $4^{\text {th }}$ sub-dimension was calculated as .77 , the $5^{\text {th }}$ sub-dimension was calculated as .82 , the $6^{\text {th }}$ sub-dimension was calculated as .76 , and the $7^{\text {th }}$ sub-dimension was calculated as .84 .

The internal consistency coefficient was recalculated in all sub-dimensions for this study, it was determined as .95 for the general of the scale. The $1^{\text {st }}$ sub-dimension was calculated as .75 , the $2^{\text {nd }}$ sub-dimension was calculated as .80 , the $3^{\text {rd }}$ subdimension was calculated as .79 , the $4^{\text {th }}$ sub-dimension was calculated as .79 , the $5^{\text {th }}$ sub-dimension was calculated as .78 , the $6^{\text {th }}$ sub-dimension was calculated as .83 , and the $7^{\text {th }}$ sub-dimension was calculated as .71. and the Cronbach Alpha values are given in Table 3.

Occupational Anxiety Scale for Prospective Teachers. "Task-Centered Anxiety" sub-dimension, which is one of the 8 sub-dimensions of the Occupational Anxiety Scale developed by Cabı and Yalçınalp (2013), was used to measure the taskcentered anxiety levels of prospective teachers in this study. The task-centered anxiety sub-dimension consists of 13 items and the highest score is 65 , indicating that the higher the score, the lower the anxiety rate. The entire professional anxiety scale consists of 45 items and 8 sub-dimensions. These are respectively; (a) Task-Centered Anxiety, (b) Economic / Social-Centered Anxiety, (c) Student / Communication-Centered Anxiety, (d) Colleague and Parent-Centered Anxiety, (e) Personal Development-Centered Anxiety, (f) Appointment-Centered Anxiety, (g) Cohesion Center Anxiety and (h) School Management Center Anxiety. Each expression that takes place in the scale has a rating Likert type, (5) I am not anxious, (4) I am slightly anxious, (3) I am partially anxious, (2) I am anxious, (1) I am very anxious. The total reliability coefficient estimated from the whole scale was determined as .95 . The lowest score that can be obtained from the scale is 45 , the highest score is 225 , and high scores indicate low occupational anxiety level. The internal consistency coefficient of the Task Center Anxiety sub-dimension was recalculated for this study and the Cronbach Alpha values are given in Table 3 .

\section{Data Analysis}

Descriptive statistics were used for the analysis of the data in this research. In advanced analysis the t-test of arithmetic averages in independent groups was conducted to compare the teaching efficacy levels and task-centered anxiety levels of physical education teacher candidates in terms of gender, grade and sports branch. Pearson Moments Product Correlation Coefficient technique was used to determine the level and 
direction of the relationship between the teaching efficacy and task-centered anxiety levels of the physical education teacher candidates. In addition, multiple regression analysis was used in order to test whether physical education teacher candidates' teaching efficacy levels affected their task-centered anxiety levels. Each of the sub-scale scores of physical education teaching efficacy scale was considered as an independent variable and task-centered anxieties of prospective physical education teachers was considered as a dependent variable in these analyzes.

\section{Results}

\section{Teaching Efficacy and Task-Centered Anxiety Levels}

The findings obtained are given in Table 3 regarding the 1st sub-problem of the research.

Table 3

Levels of Teaching Efficacy \& Task-Centered Anxiety

\begin{tabular}{lcc}
\hline Variables $(n=228)$ & $M$ & SD \\
\hline Efficacy about PE content knowledge & 10.386 & 2.398 \\
Efficacy for applying scientific knowledge in teaching PE & 8.622 & 2.043 \\
Efficacy about accommodating skill level differences & 11.600 & 2.404 \\
Efficacy for teaching students with special needs & 11.052 & 2.631 \\
Efficacy about instruction & 14.057 & 2.950 \\
Efficacy for using assessment & 11.434 & 2.413 \\
Efficacy for using technology & 11.675 & 2.597 \\
Teaching Efficacy (Total) & 78.828 & 13.917 \\
Task-Centered Anxiety & 39.271 & 8.726 \\
\hline
\end{tabular}

When Table 3 is examined, it has been observed that prospective physical education teachers have high levels of teaching efficacy in 7 sub-dimensions and, as a reflection of this, their teaching efficacy levels are high. In addition, it was determined that task-centered anxiety levels were also intermediate (optimum level). 
Comparison of Teaching Efficacy and Task-Centered Anxiety Levels According to Gender, Grade and Sports Branch Variables

The findings obtained are given in Table 4 regarding the 2 nd sub-problem of the research.

Table 4

Comparison of Teaching Efficacy and Task-Centered Anxiety Levels According to Gender, Grade and Sports Branches

\begin{tabular}{|c|c|c|c|c|c|c|c|c|}
\hline & iables & & $n$ & $M$ & $S D$ & $D f$ & $t$ & $p$ \\
\hline \multirow{6}{*}{ Teaching Efficacy } & \multirow{2}{*}{ Gender } & Female & 84 & 80.547 & 13.111 & 226 & \multirow{2}{*}{-1.427} & \multirow{2}{*}{.155} \\
\hline & & Male & 144 & 77.826 & 14.316 & & & \\
\hline & \multirow{2}{*}{ Grade } & 3rd grade & 130 & 78.430 & 12.544 & 226 & \multirow{2}{*}{-.497} & \multirow{2}{*}{.620} \\
\hline & & 4th grade & 98 & 79.357 & 15.605 & & & \\
\hline & \multirow{2}{*}{$\begin{array}{l}\text { Sports } \\
\text { Branch }\end{array}$} & Individual & 88 & 81.113 & 13.034 & 226 & \multirow{2}{*}{1.978} & \multirow{2}{*}{.059} \\
\hline & & Team sports & 140 & 77.392 & 14.304 & & & \\
\hline \multirow{6}{*}{$\begin{array}{c}\text { Task-Centered } \\
\text { Anxiety }\end{array}$} & \multirow{2}{*}{ Gender } & Female & 84 & 39.976 & 7.867 & 226 & \multirow{2}{*}{-0.930} & \multirow{2}{*}{.353} \\
\hline & & Male & 144 & 38.861 & 9.192 & & & \\
\hline & \multirow{2}{*}{ Grade } & 3rd grade & 130 & 39.884 & 8.601 & 226 & \multirow{2}{*}{1.222} & \multirow{2}{*}{.223} \\
\hline & & 4 th grade & 98 & 38.459 & 8.869 & & & \\
\hline & \multirow{2}{*}{$\begin{array}{l}\text { Sports } \\
\text { Branch }\end{array}$} & Individual & 88 & 38.318 & 8.479 & 226 & \multirow{2}{*}{-1.310} & \multirow{2}{*}{.191} \\
\hline & & Team sports & 140 & 39.871 & 8.856 & & & \\
\hline
\end{tabular}

$* p<.05$

When Table 4 is examined, it was observed that the differences between arithmetic averages of teaching efficacy levels and task-centered anxiety levels were not statistically significant in terms of gender, grade and sports branch. 


\section{Relationship between Teaching Efficacy and Task-Centered Anxiety}

The findings obtained are given in Table 5 regarding the $3 \mathrm{rd}$ sub-problem of the research.

Table 5

Relationship between Teaching Efficacy \& Task Centered Anxiety Levels

\begin{tabular}{|c|c|c|c|c|c|c|c|c|c|}
\hline Variables & (A) & (B) & (C) & (D) & (E) & (F) & (G) & $(\mathrm{H})$ & (I) \\
\hline (A) & 1 & & & & & & & & \\
\hline (B) & $.652 * *$ & 1 & & & & & & & \\
\hline (C) & $.366 * *$ & $.486 * *$ & 1 & & & & & & \\
\hline (D) & $.546 * *$ & $.629 * *$ & $.570 * *$ & 1 & & & & & \\
\hline (E) & $.503 * *$ & $.508 * *$ & $.622 * *$ & $.687 * *$ & 1 & & & & \\
\hline$(\mathrm{F})$ & $.511 * *$ & $.531 * *$ & $.540 * *$ & $.628 * *$ & $.708 * *$ & 1 & & & \\
\hline (G) & $.468 * *$ & $.491 * *$ & $.569 * *$ & $.631 * *$ & $.679 * *$ & $.648 * *$ & 1 & & \\
\hline$(\mathrm{H})$ & $.717 * *$ & $.753 * *$ & $.747 * *$ & $.846 * *$ & $.860 * *$ & $.823 * *$ & $.813 * *$ & 1 & \\
\hline (I) & $.410 * *$ & .298 & $.278 * *$ & .459 & $.373 * *$ & .241 & .239 & $.479 * *$ & 1 \\
\hline$M$ & 10.386 & 8.622 & 11.600 & 11.052 & 14.057 & 11.434 & 11.675 & 78.828 & 39.271 \\
\hline SD & 2.398 & 2.043 & 2.404 & 2.631 & 2.950 & 2.413 & 2.597 & 13.917 & 8.726 \\
\hline
\end{tabular}
(A) Efficacy about PE content knowledge
(B) Efficacy for applying scientific knowledge in teaching PE
(C) Efficacy about accommodating skill level differences
(D) Efficacy for teaching students with special needs
(E) Efficacy about instructions
(F) Efficacy for using assessment
(G) Efficacy for using technology
(H) Teaching Efficacy (Total)
(i) Task-Centered Anxiety

When Table 5 is examined, It was determined that there was a moderate positive relationship between the total teaching efficacy levels $(r=.479, p<.01)$ and task-centered anxiety levels. In addition, it was observed that there was a positive and low level relationship between the adequacy levels of the $(p<.01)$ sub-dimensions efficacy about PE content knowledge ( $r=.410, p<.01)$, efficacy for teaching students with special needs $(r=0.459, p<.01)$, efficacy for applying scientific knowledge in teaching PE $(r=.298$, $p<.01)$, efficacy about accommodating skill level differences $(r=.278, p<.01)$, efficacy about instruction $(r=.373, p<.01)$, efficacy for using assessment $(r=.241, p<.01)$, efficacy for using technology $(r=.239, p<.01)$, and task-centered anxiety levels. 


\section{Prediction Validity of Teaching Efficacy on Task-Centered Anxiety}

The findings obtained are given in Table 6 regarding the 4th sub-problem of the research.

Table 6

Regression Analysis Results Regarding Prediction of Task-Centered Anxiety Levels

\begin{tabular}{|c|c|c|c|c|c|c|c|}
\hline Variables & $B$ & $\begin{array}{c}\text { Standard } \\
\text { Error }_{\mathrm{B}}\end{array}$ & $\beta$ & $T$ & $p$ & $\begin{array}{c}\text { Dual } \\
r\end{array}$ & $\begin{array}{c}\text { Partial } \\
r\end{array}$ \\
\hline Constant & 57.422 & 3.152 & - & 18.218 & .000 & - & - \\
\hline Efficacy PE content knowledge & .370 & .458 & .102 & .808 & .420 & .410 & .054 \\
\hline $\begin{array}{l}\text { Efficacy for applying scientific } \\
\text { knowledge in teaching PE }\end{array}$ & .650 & .479 & .152 & 1.357 & .176 & .298 & .091 \\
\hline $\begin{array}{l}\text { Efficacy about accommodating } \\
\text { skill level differences }\end{array}$ & .652 & .482 & .180 & 1.352 & .178 & .278 & .091 \\
\hline $\begin{array}{l}\text { Efficacy for teachings students } \\
\text { with special needs }\end{array}$ & .293 & .503 & .088 & .583 & .560 & .459 & .039 \\
\hline Efficacy about instruction & .436 & .518 & .134 & 1.215 & .219 & .373 & .063 \\
\hline Efficacy for using assessment & 1.325 & .531 & .366 & 2.495 & .013 & .241 & .166 \\
\hline Efficacy for using technology & 1.180 & .484 & .351 & 2.438 & .016 & .239 & .162 \\
\hline Teaching Efficacy (Total) & -.854 & .308 & -1.362 & -2.773 & $.006^{*}$ & .479 & -.184 \\
\hline$R=.430$ & & $R^{2}=.185$ & & & & & \\
\hline$F_{(7.220)}=7.122$ & & $p=.000$ & & & & & \\
\hline
\end{tabular}

When Table 6 is examined; the equation for predicting task-centered anxiety levels of teaching competency scale sub-dimensions $(F=7.122, p<.01)$ was noted as important. The variables constituting the sub-dimension of teaching efficacy, accounted for $19 \%$ of the total variance in task-centered anxiety levels. According to the standardized regression coefficient $(\beta)$, the predictor variables' order of was as follows: total teaching efficacy levels, efficacy for using assessment, efficacy for using technology, efficacy about accommodating skill level differences, efficacy for applying scientific knowledge in teaching PE, efficacy about instruction, efficacy about PE content knowledge and efficacy for teaching students with special needs. When the results related to the significance of the regression coefficients were examined, it was observed that only the total teaching efficacy levels coefficients variables were a significant and important predictor of task-centered anxiety levels.

\section{Discussion and Conclusion}

In this study, it was observed that the prospective physical education teachers had a high level of efficacy in 7 sub-dimensions and as a reflection of this, the level of teaching efficacy was high. In addition, it was determined that task-centered anxiety levels were also at mid-level (optimum). In addition, the differences between the teaching efficacy levels and task-centered anxiety levels of physical education teacher candidates are not statistically significant in terms of gender, grade and sports branch. It 
was determined that there was a moderate positive relationship between the total teaching efficacy levels and task-centered anxiety levels. In addition, it was observed that there was a positive and low level relationship between the adequacy levels of the sub-dimensions efficacy about PE content knowledge, efficacy for teaching students with special needs, efficacy for applying scientific knowledge in teaching PE, efficacy about accommodating skill level differences, efficacy about instruction, efficacy for using assessment, efficacy for using technology, and task-centered anxiety levels. However, when the results related to the significance of the regression coefficients are analyzed, it was determined that only the total teaching efficacy levels are a significant and important predictor of task-centered anxiety levels.

It has been observed that the teaching efficacy levels of physical education teacher candidates are high in both scale total and 7 sub-dimensions. Many studies (Karacaoğlu, 2008; Saracaloğlu, Certel, Varol, \& Bahadır, 2012; Varol \& Türkmen, 2017) were found to produce similar results. In addition, studies that differed from the research results (Erbaş, Varol, Erdoğdu, \& Ünlü, 2014; Pehlivan, 2010; Slaybaugh, Evans, \& Byrd, 2004; Ünlü, 2013) were found. In some studies, it has been stated that prospective physical education teachers receive training on real practice that they will encounter in the field of teaching, and that prospective teachers have the opportunity to apply the theoretical knowledge they received in their practice training as a reason that increases their teaching efficacy (Aydın, 1998). Especially in recent years, because of the more strict control of prospective teachers' school experience and teaching practice lessons by the Ministry of Education, the increase in the practice experience of prospective teachers can be considered as a factor in this result.

Task-centered anxiety levels of physical education teacher candidates were found to be optimal. Although there are studies that support this result, some studies with different results have been found. There is a direct relationship between the level of anxiety and performance; in cases where anxiety rate is too low or too high, performance generally decreases, while anxiety is at optimal level, it is stated that high performance is obtained (Gould, Udry, Tuffey, \& Loehr, 1997). In this study, it is thought that the task-centered anxiety levels of the physical education teacher candidates with high teaching efficacy levels are an expected result considering the relationship between performance and anxiety.

It was observed that the differences between the teaching efficacy levels of the physical education teacher candidates and the arithmetic averages of task-centered anxiety levels were not statistically significant in terms of gender, grade and sports branch. While this result is in line with some similar studies (Alrabai, 2015; Cheok \& Wong, 2015; Erbaş, 2014), many similar studies have shown different results (Gözler, Bozgeyikli, \& Avc1, 2017; McLean, Abry, Taylor, Jimenez, \& Granger, 2017; Muñoz, Penalba, Sánchez, \& Santos, 2017; Saracaloğlu, Kumral, \& Kanmaz, 2009). In two different studies, it was observed that gender factor is an important variable and especially female teacher candidates' perception of teaching efficacy is high and their professional anxiety are at optimum level (Erbaş, 2014; Saracaloğlu et al., 2009).

Although the grade is an important variable for teaching efficacy and taskcentered anxiety, due to the fact that prospective teachers' school experience lesson and teaching practice lessons show parallelism in the field of application; This study can be 
considered as the reason for the absence of a significant difference. Again, the reason for not having a significant difference in terms of gender, which is seen as an important variable; It can be thought that it is due to the ratio of female-male teacher candidates in the research group. As a matter of fact, it has been stated in some studies that female teacher candidates have higher levels of anxiety compared to males in terms of research and teaching efficacy level, and they also have higher levels of anxiety than males. As a reason, it was stated that female individuals in Turkish society are more anxious in terms of acquiring a profession and being able to perform the profession (Pehlivan, 2010; Taşğın, 2006).

It was determined that there was a moderate positive relationship between the total teaching efficacy levels and task-centered anxiety levels. In addition, it was observed that there was a positive and low level relationship between the adequacy levels of the sub-dimensions efficacy about PE content knowledge, efficacy for teaching students with special needs, efficacy for applying scientific knowledge in teaching PE, efficacy about accommodating skill level differences, efficacy about instruction, efficacy for using assessment, efficacy for using technology, and task-centered anxiety levels. This result is in line with similar studies (Brown, et al., 2015; Dickson, McMinn, \& Kadbey, 2017; Palmer, Dixon, \& Archer, 2015; Song, 2016). Furthermore, there are also different studies from these results. It was observed that Senler (2016) showed a negative relationship between the attitudes of science teacher candidates towards science teaching and their anxiety levels and that the attitude towards science teaching had a negative effect on anxiety (Senler, 2016). As mentioned before; there is a direct relationship between the level of anxiety and performance; In cases where anxiety rate is too low or too high, performance generally decreases, while anxiety is at optimal level, it is stated that high performance is obtained (Gould, et al., 1997). Accordingly, the positive relationship between high level physical education teaching efficacy and task-centered anxiety can be explained. Since anxiety score increases here, it means that the level of anxiety decreases, the positive relationship should be evaluated in this direction.

When the results related to the significance of the regression coefficients are analyzed, it was determined that only the total teaching efficacy levels are a significant and important predictor of task-centered anxiety levels. This situation can be evaluated as the result that Fuller's (1969) theory on anxiety is tested again in terms of taskcentered anxiety. Some studies supporting this result have been found (Fuller, 1969; Meek \& Behets, 1999; Wendt, Bain, \& Jackson, 1981). Teaching efficacy is a reflection of the pre-service education process of physical education teacher candidates, and it can be considered as an expected result that the level of anxiety expressed by the situation they will encounter before starting the task is a meaningful and important predictor.

\section{Implications}

In line with all these results; it has been concluded that the quality of pre-service education, which is considered to be the most important determinant of the taskcentered anxiety of a physical education teacher candidates who will start to work, and to increase and update the quality of undergraduate programs that train physical education teachers in this direction. 


\section{Statement of Responsibility}

Mustafa Kayıhan Erbaş; conceptualization, methodology, validation, formal analysis, investigation, resources, data curation, writing - original draft, writing - review \& editing, visualization, supervision. Hüseyin Ünlü; conceptualization, methodology, validation, writing - review \& editing, supervision.

\section{References}

Alrabai, F. (2015). The influence of teachers' anxiety-reducing strategies on learners' foreign language anxiety. Innovation in Language Learning and Teaching, 9(2), 163-190. http://dx.doi.org/10.1080/17501229.2014.890203

Aydın, A. (1998). Eğitim fakültelerinin yeniden yapılandırılması ve öğretmen yetiştirme sorunu. Kuram ve Uygulamada Eğitim Yönetimi Dergisi, 4(3), 275-286.

Aydın, A., \& Tekneci, E. (2013). Attitudes towards profession and anxiety levels of education of mentally handicapped students. Pegem Ĕgitim ve Öğretim Dergisi, 3(2), 01-12.

Bandura, A. (1986). The explanatory and predictive scope of self-efficacy theory. Journal of Social and Clinical Psychology, 4(3), 359-373.

Bartholomew, K. J., Ntoumanis, N., Cuevas, R., \& Lonsdale, C. (2014). Job pressure and ill-health in physical education teachers: The mediating role of psychological need thwarting. Teaching and Teacher Education, 37, 101-107. . http://dx.doi.org/10.1016/j.tate.2013.10.006

Bedir, G. (2015). Perception of teaching efficacy by primary and secondary school teachers. International Electronic Journal of Elementary Education, 8(1), 41-54.

Boz, Y. (2008). Turkish student teachers' concerns about teaching. European Journal of Teacher Education, 31(4), 367-377.

http://dx.doi.org/10.1080/02619760802420693

Brown, A. L., Lee, J., \& Collins, D. (2015). Does student teaching matter? Investigating pre-service teachers' sense of efficacy and preparedness. Teaching Education, 26(1), 77-93. . http://dx.doi.org/10.1080/10476210.2014.957666

Cabı, E., \& Yalçınalp, S. (2013). Öğretmen adaylarına yönelik mesleki kaygı ölçeği (MKÖ): Geçerlik ve güvenirlik çalışması. Hacettepe Üniversitesi Eğitim Fakültesi Dergisi, 44(44), 85-96.

Cheok, M. L., \& Wong, S. L. (2015). Predictors of e-learning satisfaction in teaching and learning for school teachers: A literature review. International Journal of Instruction, 8(1), 75-90.

Cochran-Smith, M. (2000). The future of teacher education: Framing the questions that matter. Teaching Education, 11(1), 13-24.

http://dx.doi.org/10.1080/10476210050020327

Deringöl, Y. (2018). Sınıf öğretmeni adaylarının matematik öğretimi kaygıları ve matematik öğretimi yeterliklerinin incelenmesi. Kuramsal Eğitimbilim Dergisi, 11(2), 261-278. 
Dickson, M., McMinn, M., \& Kadbey, H. (2017). Science anxiety levels in Emirati student teachers. Learning and Teaching in Higher Education: Gulf Perspectives, 14(1), 1-14.

Erbaş, M. K. (2014). The relationship between alienation levels of physical education teacher candidates and their attitudes towards the teaching profession. Australian Journal of Teacher Education, 39(8), 37-52.

Erbaş, M. K., Varol, Y. K., Erdoğdu, M., \& Ünlü, H. (2014). Teaching efficacy of physical education teacher candidates. Journal of Education and Practice, 5(19), 34-43.

Erbaş, M. K., Varol, Y. K., \& Ünlü, H. (2014). Beden eğitimi öğretim yeterliliği ölçeğinin Türkçe uyarlaması: Geçerlik ve güvenirlik çalışması. CBÜ Beden Eğitimi ve Spor Bilimleri Dergisi, 6(1), 16-27.

Fuller, F. F. (1969). Concerns of teachers: A developmental conceptualization. American Educational Research Journal, 6(2), 207-226.

Gould, D., Udry, E., Tuffey, S., \& Loehr, J. (1997). Burnout in competitive junior tennis players: III. Individual differences in the burnout experience. The Sport Psychologist, 11(3), 257-276. http://dx.doi.org/10.1123/tsp.11.3.257

Gözler, A., Bozgeyikli, H., \& Avc1, A. (2017). Sınıf öğretmeni adaylarının başarı yönelimleri ile mesleki kayg1 düzeylerinin incelenmesi. Abant İzet Baysal Üniversitesi Ĕ̈itim Fakültesi Dergisi, 17(1), 189-211.

Guskey, T. R., \& Passaro, P. D. (1994). Teacher efficacy: A study of construct dimensions. American Educational Research Journal, 31(3), 627-643.

Güngör, F., \& Yayl1, D. (2012). Self-efficacy and anxiety perceptions of pre-service EFL teachers. In A. Akbarov V. Cook (Eds), Approaches and methods in second and foreign language teaching (pp. 227-236). Sarajevo: IBU Publications.

Housego, B. E. (1990). Student teachers' feelings of preparedness to teach. Canadian Journal of Education/Revue Canadienne De L'education, 15(1), 37-56.

Humphries, C. A., Hebert, E., Daigle, K., \& Martin, J. (2012). Development of a physical education teaching efficacy scale. Measurement in Physical Education and Exercise Science, 16(4), 284-299. http://dx.doi.org/10.1080/1091367X.2012.716726

Kafkas, M. E., Açak, M., Çoban, B., \& Karademir, T. (2010). Beden eğitimi öğretmen adaylarının öz yeterlik algıları ile mesleki kaygıları arasındaki ilişki. İnönü Üniversitesi Ë̆itim Fakültesi Dergisi, 11(2), 94-112.

Karacaoğlu, Ö. C. (2008). Öğretmenlerin yeterlilik algıları. Yüzüncü Yll Üniversitesi Eğitim Fakültesi Dergisi, 5(1), 70-97.

Karasar, N. (2009). Bilimsel araştırma yöntemi: Kavramlar-ilkeler-teknikler. Nobel Yayın Dağıtım, Ankara.

Kırbaşlar, F. G., Veyisoğlu, A., \& Özsoy-Güneş, Z. (2015). Investigating the relationships between pre-service science teachers' self-efficacy in laboratory and anxiety towards chemistry laboratory. Procedia-Social and Behavioral Sciences, 174, 43-50. http://dx.doi.org/10.1016/j.sbspro.2015.01.624 
Martin, J. J., \& Kulinna, P. H. (2005). A social cognitive perspective of physical activity related behavior in physical education. Journal of Teaching in Physical Education, 24, 265-281. http://dx.doi.org/10.1123/jtpe.24.3.265

McLean, L., Abry, T., Taylor, M., Jimenez, M., \& Granger, K. (2017). Teachers' mental health and perceptions of school climate across the transition from training to teaching. Teaching and Teacher Education, 65, 230-240. http://dx.doi.org/10.1016/j.tate.2017.03.018

Meek, G. A., \& Behets, D. (1999). Physical education teachers' concerns towards teaching. Teaching and Teacher Education, 15(5), 497-505. http://dx.doi.org/10.1016/S0742-051X(98)00061-4

MoNE. (2017). Öğretmenlik mesleği genel yeterlikleri, Ankara: Öğretmen Yetiştirme ve Geliştirme Genel Müdürlüğü. Retrieved from www.oygm.meb.gov.tr

Muñoz, O. R., Penalba, F. A., Sánchez, J. F., \& Santos, O. C. (2017). Reducing technoanxiety in high school teachers by improving their ICT problem-solving skills. Behaviour \& Information Technology, 36(3), 255-268. http://dx.doi.org/10.1080/0144929X.2016.1221462

Palmer, D., Dixon, J., \& Archer, J. (2015). Changes in science teaching self-efficacy among primary teacher education students. Australian Journal of Teacher Education, 40(12), 27-40.

Pehlivan, Z. (2010). Analysis of physical self-perceptions of physical education teacher candidates and their attitudes toward teaching profession. Education and Science, 35(156), 126-141.

Price, H. E., \& Weatherby, K. (2018). The global teaching profession: how treating teachers as knowledge workers improves the esteem of the teaching profession. School Effectiveness and School Improvement,29(1), 113-149. http://dx.doi.org/10.1080/09243453.2017.1394882

Saban, A., Korkmaz, İ., \& Akbaşlı, S. (2004). Öğretmen adaylarının mesleki kaygıları. Ĕ̈itim Araştırmaları Dergisi, 17, 198-209.

Saracaloğlu, A. S., Kumral, A., \& Kanmaz, O. (2009). Ortaöğretim sosyal alanlar öğretmenliği tezsiz yüksek lisans öğrencilerinin öğretmenlik mesleğine yönelik yeterlikleri, kaygıları ve akademik güdülenme düzeyleri. Yüzüncü Yıl Üniversitesi Ĕ̈itim Fakültesi Dergisi, 6(2), 38-54.

Saracaloğlu, A. S., Certel, Z., Varol, S. R., \& Bahadır, Z. (2012). Beden Eğitimi Öğretmenlerinin Özyeterlik İnançları ve Denetim Odaklarının İncelenmesi. Adnan Menderes Üniversitesi Ĕ̆itim Fakültesi Eğitim Bilimleri Dergisi, 3(2), 54-65.

Senler, B. (2016). Pre-service science teachers' self-efficacy: The role of attitude, anxiety and locus of control. Australian Journal of Education, 60(1), 26-41. http://dx.doi.org/10.1177/0004944116629807.

Slaybaugh, J., Evans, C., \& Byrd, R. (2004). Second-year teachers' attitudes toward the teaching profession. National Forum of Teacher Education Journal, 14(3), 31-36.

Song, C. (2016). Supervisors' paternalistic leadership influences college English teachers' teaching efficacy in China. Social Behavior and Personality, 44(8), 13151328. http://dx.doi.org/10.2224/sbp.2016.44.8.1315. 
Summers, J. J., Davis, H. A., \& Woolfolk Hoy, A. (2017). The effects of teachers' efficacy beliefs on students' perceptions of teacher relationship quality. Learning and Individual Differences, 53, 17-25.

http://dx.doi.org/10.1016/j.lindif.2016.10.004

Taşğın, Ö. (2006). Beden eğitimi ve spor yüksekokulunda okuyan öğretmen adaylarının mesleki kaygı düzeylerinin bazı değişkenler açısından incelenmesi. Kastamonu Ĕ̈itim Dergisi, 14(2), 679-686.

Ünlü, H. (2013). Do prospective physical education teachers really want to be physical education teachers? Croatian Journal of Education, 15(Sp. Ed. 4), 211-230.

Ünlü, H., \& Erbaş, M. K. (2018). Beden eğitimi öğretmen adaylarının akademik özyeterlikleri ve mesleki kaygıları. Türkiye Spor Bilimleri Dergisi, 2(1), 15-25.

Varol, S., \& Türkmen, M. (2017). Beden eğitimi öğretmeni adayı son sınıf öğrencilerinin beden eğitimi öğretim yeterlilik alg1 düzeylerinin belirlenmesi. Uluslararası Kültürel ve Sosyal Araştırmalar Dergisi (UKSAD), 3(2), 330-342.

Wendt, J. C., Bain, L. L., \& Jackson, A. S. (1981). Fuller's concerns theory as tested on prospective physical educators. Journal of Teaching in Physical Education, 1(1), 66-70. http://dx.doi.org/10.1123/JTPE.1.s1.66

Woolfolk Hoy, A., \& Davis, H. (2005). Teachers' sense of efficacy and adolescent achievement. Adolescence and Education, 5, 117-137.

This is an Open Access article distributed under the terms of the Creative CommonsAttributionNonCommercial-ShareAlike 4.0 International (CC BY-NC-SA 4.0). For further information, you can refer to https://creativecommons.org/licenses/by-nc-sa/4.0/ 